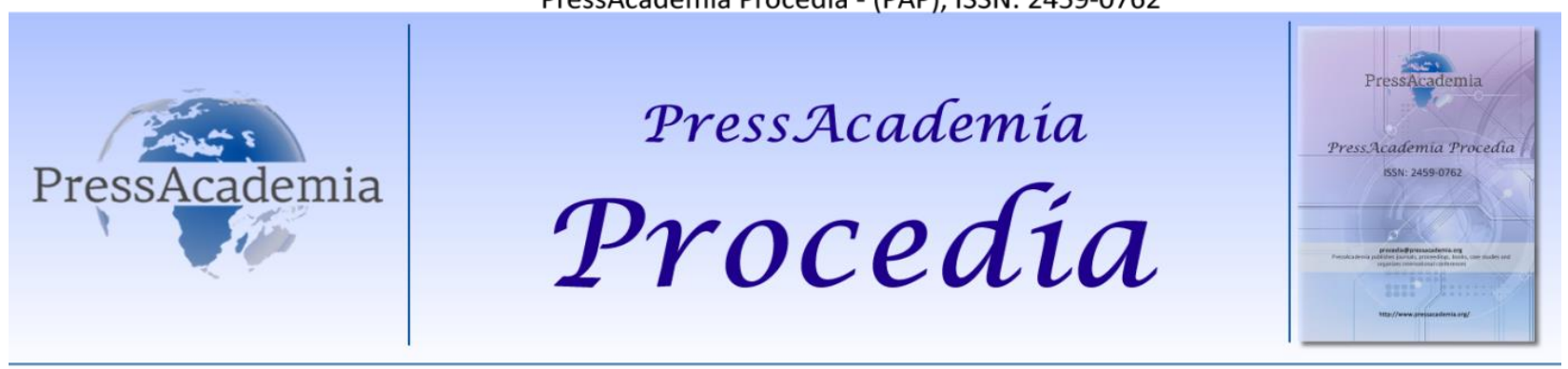

2nd World Conference on Technology, Innovation and Entrepreneurship

May 12-14, 2017, Istanbul, Turkey. Edited by Sefer Şener

\title{
PLACE AND IMPORTANCE OF HUMAN RESOURCES MANAGEMENT IN HOTEL OPERATIONS
}

\author{
DOI: 10.17261/Pressacademia.2017.543 \\ PAP-WCTIE-V.4-2017(35)-p.265-272
}

Mustafa Tandogan

Near East University, Nicosia. antalyamavi@gmail.com

\begin{abstract}
As nowadays technology production is out of monopoly of certain countries, it also possible for countries that don't have necessary equipment for technology production to acquire them by copying. In this context every other resource except human resources can be bought, substituted or acquired by various means. Human resource is hardest to acquire and the most expensive. The most important feature of the tourism sector whose importance is ever-growing today and the future is it being a service sector. Therefore, the only way to reach maximum quality of touristic products is manpower. Within hotel operations, running services and satisfying customers are largely provided by the effort of personnel. For this reason; human resources is very important for the efficiency of hotel operations. Operations that adopts a modern manner of management, practices human resource management techniques that ensures the employment of right person, in the right place and the right time. It is clear that competitive power increases by the correct planning of human resources in an operation. In hotel operations, "human" factor is the one that creates both the income and expenditure. Good management of human resources factor will ensure efficient use of manpower in businesses. In a sector such as hotel managements, that face-to-face relationships and the case of "service of a human to a human" happens densely, management of human resources is only possible by a Human Resources Management which requires special knowledge and skill in this field. Human resources management is a discipline that educates the personnel, improve their knowledge and skill, motivate and ensure them being satisfied with their work. For hotel operations to adopt and practice the mentality of human resources management will ensure their continued existence. Keywords: Place And Importance, Human Resources Management, Hotel Operations
\end{abstract}

Keywords: Place and Importance, Human Resources Management, Hotel Operations JEL Codes: N25, M15,I23

\section{INTRODUCTION}

As nowadays technology production is out of monopoly of certain countries, it also possible for countries that don't have necessary equipment for technology production to acquire them by copying. In this context every other resource except human resources can be bought, substituted or acquired by various means. Human resource is hardest to acquire and the most expensive. The most important feature of the tourism sector whose importance is ever-growing today and the future is it being a service sector. Therefore, the only way to reach maximum quality of touristic products is manpower. Within hotel operations, running services and satisfying customers are largely provided by the effort of personnel. For this reason; human resources is very important for the efficiency of hotel operations. Operations that adopt a modern manner of management, practice human resource management techniques that ensure the employment of right person in the right place and time. It is clear that competitive power increases by the correct planning of human resources in an operation.

In hotel operations, "human" factor is the one that creates both the income and expenditure. Good management of human resources factor will ensure efficient use of manpower in businesses. In a sector such as hotel managements, that face-toface relationships and the case of "service of a human to a human" happens densely, management of human resources is only possible by a Human Resources Management which requires special knowledge and skill in this field. Human resources management is a discipline that educates the personnel, improve their knowledge and skill, motivate and ensure them being satisfied with their work. For hotel operations to adopt and practice the mentality of human resources management will ensure their continued existence. 


\section{PLACE AND IMPORTANCE OF HUMAN RESOURCES ON HOTEL OPERATIONS \\ 2.1 Human Element in Hotel Operations}

Tourism sector, which falls into services sector in modern economic structure, apart from other sectors, looks like a sequence of sectors. Since there are productions in accommodation, catering, transportation, communication, entertainment and similar economic sectors, it demonstrates a widespread and complicated sectorial structure. 'The most important feature of the tourism sector whose importance is ever-growing today and the future is it being a service sector, therefore only way of reaching quality in touristic products, depends on manpowerii. No other economic sector is related to humans or individuals as much as tourism sector is. The most important element, while on one hand creating tourism demand by individual activities and direct actions, on the other hand adding meaning to tourism supply and rendering it possible to respond to demands, is again, individuals ${ }^{\text {iii }}$. Modern management approaches value human dimension of an organization greatly. Since human dimension remains at the forefront of service sector, therefore of hotel operations, this condition gains importance more apparently. For as much as accommodation sector has the obligation to employ qualified workforce. That is, because principals of hotel management is based on "manpower". Importance of human element as a production factor is felt deeper in hotel operations compared to others. In hotel operations, answering phones, cleaning rooms, welcoming and admitting customers, preparing food and beverage, doing the dishes, service and fixing equipment, electrical and water installations etc. all done by working personnel. Primary element of "hospitality services", which is the most important function of hotel operations, is manpower. Since human dimension remains at the forefront of service sector, therefore of hotel operations this condition gains importance more apparently. Accommodation sector is a sector that has the obligation to employ qualified work-force. ${ }^{\text {iv }}$ Qualification of human resources employed in hotel operations has great importance. Most important feature separating personnel who have appropriate demographic features, professional competency and experience from the others is qualitative values. Qualification of present human resources has an important influence on the success of a business manager. What is more important than the quantity of personnel in a business is the values they have in terms of qualification. Quality of the work done only shows itself with employees' experience and qualifications. Qualifications of work-force are closely associated with general and occupational level of education of employed personnel. Education, apart from opportunities such as general, technical and occupational knowledge, physical or secret talents, undertakes a series of duties such as connecting and integrating personnel to the business, drawing them into close cooperation and ensuring social symphysis.

Importance of teamwork on the success of businesses is gradually increasing. Communication between employees is one of the most important subjects in hotel operations. Increasing effectiveness of employees, facilitating works, ensuring cooperation between employees and conveniently reaching subjects that the management want to transmit to the employees is achieved by implementing efficient communication techniques. Even though communication techniques to be implemented should be improved by business management, it is necessary for employees to have natural communication skills. Human resource, having tourism consciousness which can be explained as honouring guests and ethics, is important for success in hotel operations. If human resources in hotel operations do not have appropriate features, that business is subject to a great deficiency. ${ }^{\vee}$ Two primary elements draw attention behind the need for manpower in hotel operations. First of them is the impossibility of implementing most of the work done without manpower no matter how much technology is used. For example, while organization of beds is done by personnel working in housekeeping, front office personnel are responsible for solving problems all customers have in entry and exit and other times. Second is, expectation of people involved in travels to have the service provided by human intervention in every stage of tourism. Personnel element, along with having an important role in organization's success, is much more important in service sector such as hotel operations. That is, because in hotel operations, most of the personnel is in direct relation with customers. Customer satisfaction is effected by politeness of personnel, helpfulness and personal traits as much as accommodation and catering standards or other facilities.

\subsection{Place and Importance of Human Resources Management in Hotel Operations}

Since mechanization and automation is not possible except for certain ratios on certain production lines, due to tourism sector being a labour-intensive sector, human factor comes to prominence. Ever-growing importance of this element in businesses caused the personnel to be seen as the most important resource in businesses that want to catch the competitive advantage. From this point of view, in hotel operations that falls into service sector and business success mainly depends on employees, this resource gains even more importance. Therefore maximum efficacy of personnel in hotel operations depends on investing on and satisfying them. ${ }^{\text {vi }}$ In short, human factor is a very important and irreplaceable factor. When this factor is put to its place within the equation that shows the success of businesses, gains even more importance against other factors involved that has a relatively stationary structure. In fact, when we speak of continuing existence of an organization, business, corporation or establishment, still the first thing that comes to mind, is that structure having people within. 
Human resources have a great role in implementation of organizational objectives in hotel operations. For this reason, in the course of time between marketing of touristic product and services, human element is effective. Human resources in hotel operations has a quite big importance due to general features of tourism. In contrary to techno-intensive features of other manufacturing businesses, tourism businesses, hence accommodation businesses, show labour-intensive features. When human resources management is evaluated from the perspective of hotel operations; it will be correct to say that this kind of management approach follows a slower progression trend in hotel sector than other sectors. Personnel policies formed in hotel operations until today, showing an emphasis on cost control rather than improvement of human resources, confirms this. ${ }^{\text {vii }}$ Human element, having this much of importance in hotel operations, created the necessity of having a separate unit concerning this field in organization. This unit passes under the name of personnel management in hotel operations and lately it can be seen that personnel management gradually leaves its place to "human resources management". HRM has a very active role in efficient usage of work-force. This situation, gains even more importance, especially in businesses like hotel operations which is based on human labour. Due to fact that, in hotel operations, "human" factor is the one that creates both the income and expenditure. Good management of human resources factor will ensure efficient use of work-force in businesses. In a sector such as hotel managements, that face-to-face relationships and the case of "service of a human to a human" happens most densely, management of human resources is only possible by a HRM which requires special knowledge and skill in this field. Today, when many self-proven hotels (like Four Seasons, Hilton, Kempinski, Sheraton) is examined, it is possible to see what lies behind their success is "investment on human". For example, Hilton Hotel, which made the start of modern hotel management in Turkey possible, in the oncoming years, undertook an important role by earning the corporate trait of training personnel who will work as managers in other hotel operations. This situation can be interpreted as the Hilton hotel chains seeing their personnel as an investment element.

Competition that increases throughout the world requires hotel operations to incline towards HRM field more. Like in many fields, HRM gains a little more importance every passing day in hotel management field as well. Primary tasks of HRM in hotel operations are; work analysis, human resources planning, finding and selecting personnel, personnel training, work and success evaluation, rewarding personnel, wage management, industry relations, providing occupational health \& safety and social aid and services. Effective execution of these elements, which are also the main functions of HRM, will ensure the efficient work of personnel, hence the business. ${ }^{\text {viii }}$

\subsection{Basic Functions of Human Resources Management in Hotel Operations}

Creating a good human resources policy and improvement of worker relations in businesses, is only possible by knowing what employees expect, in return of the works they are doing, before everything else. It is possible to summarize what individuals expect form the business in return for their work like these ${ }^{\text {ix }}$ :

Receiving payment which is in exchange for work done,

Work safety,

Normal working hours,

- Suitable and safe workspace,

- $\quad$ Feeling the emotion of being part of the work done,

- Individual belief of promotion in their job depending on their work and talent.

Improving good relations with employees and creating a good human resources policy by fulfilling said expectations, depends on the optimal implementation of the basic functions of HRM. Required functions to render human resources in businesses effective and efficient are explained respectively below.

\subsubsection{Planning Necessary Human Resource for the Hotel}

From the perspective of hotel operations, HRP, which is effective on offering better service to the customer by ensuring appropriate worker selection and employment, saving only by worker quantity, not playing expense decreasing role, is one of the main factors which influences efficiency, hence lucrativeness. Since it is not possible to accomplish HRM functions without knowing how much or how qualified worker need is, hotel operations are required to make a good HRM before passing on to other HRM functions. When these factors are kept in mind, importance of HRM can be summarised like this:

- HRM ensures a basis for creating and sustaining an effective workforce in an organization.

- This function of HRM, makes it possible to control workforce costs and increase employee efficiency, hence general efficiency of business.

- Furthermore, HRM contributes to achievement of short and long term strategic aims of the organization.

When human resources planning is examined from the perspective hotel operations, because of the labour intensive trait of hotel operations, workforce costs have a significant place among total costs. This situation makes an effective human 
resources planning mandatory. With an effective human resources planning, while employee turnover rate and costs are reduced, at the same time employee morale and efficiency will increase and therefore it will be ensured that service quality and customer satisfaction will reach the highest level. ${ }^{x}$ With this, by the means of human resources planning, qualitative and quantitative criteria towards recruitment and selection of workforce the organizations need is determined.

\subsubsection{Making Workforce Analysis for In-Tray}

Services given in hotel operations are generally aimed at nourishment, entertainment and relaxation along with accommodation. Accommodation businesses that aim to give these services should inspect details regarding the in-tray and it should be clearly identified how these works will be carried out and which equipment will be used. Job and task definitions must be made accordingly. ${ }^{\mathrm{x}}$

\subsubsection{Finding and Selecting Employees}

One of the most important functions of human resources management, finding and selecting employees, has a big role in the success of the business. Reaching business goals and effective and efficient use of workers will only be possible by human resources selecting the right employee to the right job. It is pointed out that hotel operations that lack a planned practice in employee recruitment, suffer at least $1 / 3$ ratio of loss. ${ }^{\text {xii }}$ Need for searching employees stems from the circumstances the business is in and its purposes. These purposes are presented with employee plans and required employee quantity and quality is determined. Information regarding qualities is obtained from workforce analysis that should have been done beforehand, job definitions and job specification forms. Before starting the exercises towards finding human resources, features needed for the employee to have and jobs currently ongoing in hotel operations must be completed, for these standard information to be obtained, work analysis must be done. With workforce analysis, every job in businesses are analysed one by one and job and task definitions are made. With these definitions, subjects like what the job is consisted of, base time, work environment, number of individuals that will do the job, job hazards are determined. Afterwards comes the selection of the most appropriate applicant, among from the group of applicants that are qualified. .iii $^{\text {in }}$

\subsubsection{Personnel Training}

To do their job the best way they can and take initiatives in their service progress, it must be ensured that commitment of employees, the competitive resources of hotel operations, is increased. For this reason, sustainability of practices of education and development is very Important. Today many hotel operations are focused on leadership style education that is prepared by managers, which motivates workforce and guides workers.

In labour intensive industries like hotel industry, education should be approached much more extensively. Because increasing service quality, abundance of workers information capacity, can only be realized by the positive change in their skill and behaviour. Because hotel management is dynamic; quality service that is compatible with ever-changing environment and customer expectations will be possible by constant education of employees. Talents of employees have decisive role on the service quality of hotel operations. Among practices of human resources management, education and development function, is described as the key factor towards ensuring service quality. In this perspective, education is a tool that eases communication between employees and with this, ensures sharing a common language and vision. Education supports harmony between employees and helps emphasize shared values. In other words, by the means of education programs within hotel operations, employees are ensured to focus on details of quality service presentation, which is the ultimate aim of the organization. Employee behaviour, which is the critical factor of service quality and customer satisfaction, gains an organizational aspect and purpose through education and development programs. Creating and practicing educational programs in hotel operations provide great benefits for both the business and employees. These benefits can be listed like this:

Benefits of Employee Training for the Business:

- Increase in learning speed,

- Improvement of performance quality,

- Decrease in number of accidents,

- Decrease in turnover rate for employees,

- Decrease in discontinuity of employees,

- Increase in production efficiency

Benefits of Employee Training for the Employees Themselves: 
- Increase in earnings,

- Easier promotion in jobs,

- Increase in self-confidence and reaching economic independence.

In order for hotel operations to comply with changing circumstances and gain competitive advantage over their rivals, "training the personnel" is fundamental. ${ }^{\text {xiv }}$

\section{HUMAN RESOURCES MANAGEMENT PROBLEMS IN HOTEL OPERATIONS}

Most important reason for selection of qualitative method is the feature of research problem. If the research requires understanding of individual's problems, experiences and thoughts, it gains even more importance for alternative methods to be qualitative. Since the purpose of research is the examination of social events in a certain environment and certain period, it is impossible for the study to be repeated in exactly the same way. For this reason, it is not possible in qualitative researches to come up with rules and standards for every environment. ${ }^{\mathrm{xv}}$

There is a holistic view in qualitative researches. Three types of data collection technique shine out in qualitative researches. These are 1) Open and unlimited meeting 2) Direct observation 3) Analysis of written documents. In these type of researches, instrument is the researcher. For this reason, skill, knowledge, ability and accuracy of the person who is going to do research with this method is important. Research is shaped by the researcher having a good command of the subject, their perspective and responsibility.

In qualitative researches data can be collected through different sources. Data is collected by the means of observation, interview and surveys. Because it is time consuming, work is done on small samples.

In this study, data is collected by the means of structured interview. Interview (meeting), is a data collection technique by verbal communication (questionnaire). Interview, even though most of the time made face-to-face, can be done by telephone or instant sound and visual transmitters. Generally, interview has three main goals:

- Ensure or sustain cooperation,

- Treatment(by increasing self-confidence),

- Collect research data.

In this research, interview is done with the goal of gathering research data. Reason for the research method to be interview technique is to speak to the right person, ensuring questions are understood correctly, belief towards getting more sincere and frank replies and receiving much more extensive information by this way. During the interview, manager can give more detailed answers to questions that can cause discomfort or subjects they want to share. With the interview technique, maybe less samples are reached but healthier results are ensured to be achieved. ${ }^{\text {xi }}$ In the research, interviews are done with 12 hotel operation officials that are in business in Istanbul. Interviews are done between the dates of 1-10 February 2011, in hours agreed mutually with hotel operation officials. Interview questions that are prepared with the help of information concerning the literature and a vast scale of questions included in the master thesis of Kolu, named "Human Resources Selection Methods Personnel Finding and Selecting Process (A Model Practice)" is used. Prepared interview questions are directed to officials and answers are requested. Results in the wake of the interview are evaluated in the findings section after interpretation. In the research, first of all, the question "How long have you been working in your current business?" is directed. Managers in 2 and 3 star hotels are determined to work for 5 and more years in the same hotels, while managers working in 4 and 5 star hotels are working in the same business for 1-4 years. To the officials participating in the research, question towards how long they have been working in tourism sector is directed. With the results by replies to these questions, it is determined that managers working in 2 and 3 star hotels have been working in tourism sector for 6-10 years, while managers working in 4-5 star hotels have been working in tourism sector for 1-5 years.

After the results of answers to the question "What is your education status", it is revealed that managers working in 2 star hotels are high school and university graduates while managers working in 3, 4 and 5 star hotels are university graduates. Question of "Do the company you are working for have a department responsible for human resources?" is directed towards participant officials. Managers working in 2, 3, 4 and 5 star hotels stated the hotels they are working in do not have a department responsible for human resources. As the result of questions directed toward the officials regarding the name of the department responsible for human resources in the business they are working for, it is determined that 2, 3, 4 star hotels do not have a department responsible for human resources, while 5 star hotels have Human Resources Department present responsible for human resources. Along with 2, 3, 4 star hotels not having human resources department, accounting department attends to personal works (wage, pay rolling). As for 5 star hotels have Human Resources Department present. ${ }^{\text {xvii }}$ 
Separated under itself, education department is also present. This shows the importance five star hotels give to education. Along with this, Personnel and Management Department takes part as well and attends to contracts, personnel recruitment and destaffing, while Human Resources Department manages orientation, moral and material rewarding arrangements and general education like worker health, safety, hygiene etc. Question of "Is the policy regarding human resources is determined in the business you are working in?" is directed to officials participating in the research. Managers working in 2, 3 and 4 star hotels replied the hotels they are working in do not have human resources policy determined, while managers working 5 star hotels replied having human resources policy determined. Answers to the question towards identifying the unit determining human resources policy in the business they are working in showed, 2, 3, and 4 star hotels not having a department determining human resources policy, while 5 star hotels determine human resources policy together with Upper Management and Human Resources Department. After the questions towards learning whether the hotels officials are working for do human resources planning or not, it is seen that 2, 3 and 4 star hotels do not have human resources planning, while 5 star hotels have human resources planning.

Regarding which department determines human resources planning in the hotels the officials are working in, results show 2, 3 and 4 star hotels do not have a department determining human resources planning, while in 5 star hotels, human resources planning is done by Upper Management together with Human Resources Department. As a result of the interviews done, it is tried to learn which managers are exercising the function of finding and selecting personnel in the business. While in 2 star hotels personnel finding and selecting function is executed by the hotel owner, in 3 and 4 star hotels this function is exercised by the hotel manager and in 5 star hotels human resources manager and manager of the department which requires the personnel exercise together. It is seen that in 2 star hotels, personal applications and background are used as source along with recommendations by employees and acquaintances, in 3 star hotels, announcement and advertisements, personal applications and background, recommendation by employees and acquaintances, employment agency and educational institutions are used as source and in 4, 5 star hotels, in order to employ personnel, promotion, internal transfer, personal applications and background, recommendations by employees and acquaintances and internet is used as source.

Regarding how often employee performance is evaluated in 1 year, it is concluded that 2, 3 and 4 star hotels do not evaluate employee performance in 1 year, while 5 star hotels evaluate employee performance 2 times in 1 year. The question "Do in-service training activities are organized towards employees in your business?" is directed at officials participating the research. It is determined that in 2, 3 and 4 star hotels in-service training activities are not organized towards employees, while in 5 star hotels in-service training activities are organized towards employees. In 5 star hotels, an employee is subjected to training from the day they start working until the day their contract of employment is expired. Given educations are repeated in certain intervals in order to not be forgotten and emphasize their importance. On the other hand, for example in order to teach English, after an examination of employees, giving lessons by opening classes according to everyone's levels is a service practiced for all departments within sustained education activity. In the interview, officials are asked what would be the reason if in-service training activities are not organized. Results show, in 2 star hotels the reason for in-service training activities not being organized is because in-service training activities are seen unnecessary, while in 3 and 4 star hotels in-service training activities is not required since workers are qualified enough in their job and in-service training activities are seen unnecessary. Officials participating to the research are asked "Which individuals in-service training is applied on?" It is determined that 2, 3 and 4 star hotels do not practice in-service training, while in 5 star hotels in-service training is practiced by different arrangements, like all newly employed employees, employees whose assignments are going to change or promoted, those displaying high performance (to gain new perspectives by sending them to different countries, providing education), those displaying low performance to undergo reeducation as to find where the problem originates from and solutions, manager candidates and managers given management trainings. It is tried to learn whether practices towards increasing employee motivation exist or not, and as a result it is determined, that in 2 and 3 star hotels there are no practices towards increasing employee motivation while in 4 and 5 star hotels there are practices towards increasing employee motivation. As a result of the question what kind of practices are there in order to increase employee motivations, along with 2 and 3 star hotels not having practices towards increasing employee motivation, according to managers, it can be said that promotions within the business are seen as a motivation increasing activity. As for 4 and 5 star hotels that are determined to have practices towards increasing employee motivation. In 4 star hotels, while material rewarding is done by selecting employee of the month, moral motivation is done by doing personnel meetings and listening complaints and requests. In 5 star hotels; there is a moral and material rewarding system. It is possible to say material rewarding is done by, bonuses every 3 months, double wage for the newlywed, child support for those with children, completely ensuring social rights and social aids(fuel aid, provision aid etc.).

Moral rewarding method shows valuing personnel at first by fulfilling vital needs best way possible. I am conveying that nourishment fields are no different than a restaurant, necessary areas for showers are arranged, personnel clothes are cleaned and offered to the personnel ready to use by my own observations. 
In addition to these, celebrating married employees, organizing personnel proms, organizing draws especially in personnel prom to allow household goods, communication devices, vacations and accommodation chances, distributing plaques and badges, sending celebration cards by the general manager in employees' birthdays, kids prom for employees' children, collective iftar dinners and birthday celebrations in personnel meetings, publishing photos of the new-born babies of the employees and individuals if they are working in the same business and cutting cake, inter-personnel bowling, chess, football, climbing, racing competitions, all these causes are big factors in increasing job efficiency of the employees.

\section{CONCLUSION}

Hotel operations which undertake pioneering role in tourism sector; is gaining more importance everyday with individuals' increasing holiday awareness. While nowadays rapidly growing technology undertaking pioneering role in all sectors and businesses, in hotel operations technology stays behind human labour. While in production businesses employee quantity and quality is seen to decrease, hotel operations preserve its trait of being labour intensive. Main factor of this is hotel operations being service businesses and majority of the expected customer service being done by employees. When people come to a hotel for accommodation, they are first welcomed by employees, while registration procedures are done by front office clerks, rooms are cleaned by housekeeping employees, their meal is prepared by cooks, services are done by service attendants and all their needs are fulfilled by employees until the moment they leave the hotel. For this reason, success of hotel operations requires having an effective human resources along with a good economic and physical structure.

In businesses like hotel operations which produces service and based on humans, success and continuity largely depends on employees' efficiency and quality. As for the basis of offering a quality service, lays the need of having a high level of morale for the employees. Effort and performance of the employees towards achieving targeted goals will increase as much as the morale and motivation of employees increase. HRM, whose main purpose is to use the human resources most effectively and efficiently possible, employing right persons for the right jobs; in other words, choosing the individuals who have the necessary knowledge, skill and ability for the job and assign these people to the most appropriate units or divisions, ensure the employees' promotions are done appropriately by their performance, motivating employees, carrying out performance evaluations of the employees objectively, paying salaries of the employees fairly, has a big role in hotel operations continuing their existence and leading the way in competition. For the business to achieve its goals, it is necessary to determine how qualified and how much personnel is needed for which jobs and when it will be required. Human resources planning is the basic planning process for the organization's human resources requirement. Success of the human resources planning largely depends on how closely human resources division correlates human resources planning with the organization's business planning. In hotel operations, services are heterogenic. Carrying out services, together with machines and equipment, mostly depends on manpower. Also, carrying out services is only possible by different divisions working together. For this and many similar reasons human resources are important for hotel operations. In this research, place and importance of human resources which has an important place among factors effecting success and failure of hotel operations, is tried to be examined in accordance with information gathered from the managers. It is seen by the results of the interviews done with the officials of hotel operations; with the increase of star counts in hotel operations, importance given to human resources increase and human resources management practices take more places accordingly.

\section{REFERENCES}

Ahmet Aktaş, Turizm İşletmeciliği ve Yönetimi, Azim Matbaacılık, Antalya 2002, s.194

Ali Yıldırım ve Hasan Şimşek, Sosyal Bilimlerde Nitel Araştırma Yöntemleri. 2. Baskı, Seçkin, Yayıncılık Ankara 2000, s.19

Alparslan Usal ve Osman Avşar Kurgun, Turizm İşletmelerinde Maliyet Analizleri, Detay Yayıncılık, Ankara 2001, s. 195

Asım Saldamlı, "Otel İşletmelerinde Stres Kaynakları ve Çalışanlar Üzerinde Etkileri: Beş Yıldızlı Otellerde Bir Uygulama”, Çukurova Üniversitesi Sosyal Bilimler Enstitüsü, Sosyal Bilimler Dergisi, Sayı 6, 2000, s.292

Barış Erdem, “Otel İşletmelerinde İnsan Kaynakları Planlamasının Yeri ve Önemi”, Balıkesir Üniversitesi Sosyal Bilimler Enstitüsü Dergisi, Cilt 7, Sayı 11, 2004, s.39-41

Cengiz Demir ve Berrin Güzel, "Planlama", Editör: Cengiz Demir, Konaklama İşletmelerinde İnsan Kaynakları Yönetimi: ílkeler ve Uygulamalar, Nobel Yayın Dağıtım, Ankara, 2005, s. 76.

Cengiz Demir, Konaklama İşletmelerinde İnsan Kaynakları Yönetimi İlkeler ve Uygulamalar, Nobel Yayın Dağıtım, Ankara 2005, s.85

Ekrem Özdemir ve Ali Talip Akpınar, “Konaklama İşletmelerinde İnsan Kaynakları Yönetimi Çerçevesinde Alanya'daki Otel ve Tatil Köylerinde Insan Kaynakları Profili”, KOÜ Sosyal Bilimler Enstitüsü Dergisi, Sayı 2, 2002, s.90.

Hüseyin Alkış ve Yüksel Öztürk, “Otel İşletmelerinde Motivasyon Faktörleri Üzerine Bir Araştırma”, Elektronik Sosyal Bilimler Dergisi, Cilt 8, Sayı 28, 2009, s. 214 
Necla Kolu, Otel İşletmelerinde İnsan Kaynakları Seçim Yöntemleri Personel Bulma ve Seçme Süreci (Örnek Bir Uygulama) Yüksek Lisans Tezi, Sakarya Üniversitesi Sosyal Bilimler Enstitüsü, 2006, s.119-121.

Niyazi Karasar, Bilimsel Araştırma Yöntemi, 20. Baskı, Nobel Yayın Dağıtım, Ankara 2009, s.165- 166

Oktay Alpugan, Küçük İşletmeler Kavramı, Kuruluşu ve Yönetimi, Ankara, Özgün Matbaacılık, 1998, s.314.

Orhan İçöz, Turizm İşletmelerinde Pazarlama İlkeler ve Uygulamalar, 2. Baskı, Turhan Kitabevi, Ankara 2001, s.15

Oya Aytemiz Seymen, İnsan Kaynakları Yönetiminde İşgören Performansının Konaklama İşletmeleri Açısından Değerlendirilmesi ve Bir Model Önerisi, Yayınlanmamış Yüksek Lisans Tezi, Balıkesir Üniversitesi Sosyal Bilimler Enstitüsü 1995, s. 6

Özkan Tütüncü ve Mahmut Demir, "Konaklama İşletmelerinde İnsan Kaynakları Kapsamında İsgücü Devir Hızının Analizi ve Muğla Bölgesi Örneği”, Dokuz Eylül Üniversitesi Sosyal Bilimler Enstitüsü Dergisi, Cilt 5, Sayı 2, 2003, s. 12.

Saime Oral, Çiçek Olgun ve Gürhan Aktaş, "Turizm Bilincinin Oluşturulmasında Yaygın Eğitimin Yeri ve Önemi", 1.Turizm Sempozyumu, 1718 Kasım, Ankara, 1994, s.221

Tamer Bolat, Turizm işletmelerinde İnsan Kaynakları Yönetimi, Hafta Sonu Semineri VII, 24-26 Kasım Erciyes Üniversitesi Nevşehir Turizm İşletmeciliği ve Otelcilik Yüksek Okulu, 2000, s. 148.

\footnotetext{
Ahmet Aktaş, Turizm İşletmeciliği ve Yönetimi, Azim Matbaacılık, Antalya 2002, s.194

ii Saime Oral, Çiçek Olgun ve Gürhan Aktaş, "Turizm Bilincinin Oluşturulmasında Yaygın Eğitimin Yeri ve

Önemi”, 1.Turizm Sempozyumu, 17-18 Kasım, Ankara, 1994, s.221

iii Orhan İçöz, Turizm İşletmelerinde Pazarlama İlkeler ve Uygulamalar, 2. Baskı, Turhan Kitabevi, Ankara 2001,s.15

iv Asım Saldamlı, "Otel İşletmelerinde Stres Kaynakları ve Çalışanlar Üzerinde Etkileri: Beş Yıldızlı Otellerde Bir Uygulama”, Çukurova

Üniversitesi Sosyal Bilimler Enstitüsü, Sosyal Bilimler Dergisi, Sayı 6, 2000, s.292

` Özkan Tütüncü ve Mahmut Demir, "Konaklama İşletmelerinde İnsan Kaynakları Kapsamında İsgücü Devir

Hızının Analizi ve Muğla Bölgesi Örneği”, Dokuz Eylül Üniversitesi Sosyal Bilimler Enstitüsü Dergisi, Cilt 5,Sayı 2, 2003 , s. 12.

vi Tamer Bolat, Turizm işletmelerinde İnsan Kaynakları Yönetimi, Hafta Sonu Semineri VII, 24-26 Kasım Erciyes Üniversitesi Nevşehir Turizm

İşletmeciliği ve Otelcilik Yüksek Okulu, 2000, s. 148.

vii Oya Aytemiz Seymen, İnsan Kaynakları Yönetiminde İşgören Performansının Konaklama İşletmeleri Açısından Değerlendirilmesi ve Bir Model Önerisi, Yayınlanmamış Yüksek Lisans Tezi, Balıkesir Üniversitesi Sosyal Bilimler Enstitüsü 1995, s. 6

viii Barış Erdem, “Otel İşletmelerinde İnsan Kaynakları Planlamasının Yeri ve Önemi”, Balıkesir Üniversitesi Sosyal Bilimler Enstitüsü Dergisi,

Cilt 7, Sayı 11, 2004, s.39-41

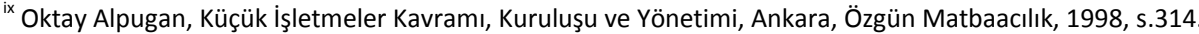

× Cengiz Demir ve Berrin Güzel, "Planlama”, Editör: Cengiz Demir, Konaklama İşletmelerinde İnsan Kaynakları Yönetimi: İlkeler ve Uygulamalar, Nobel Yayın Dağıtım, Ankara, 2005, s. 76.

xi Ekrem Özdemir ve Ali Talip Akpınar, "Konaklama İşletmelerinde İnsan Kaynakları Yönetimi Çerçevesinde Alanya'daki Otel ve Tatil Köylerinde İnsan Kaynakları Profili", KOÜ Sosyal Bilimler Enstitüsü Dergisi, Sayı 2, 2002, s.90.

xii Cengiz Demir, Konaklama İşletmelerinde İnsan Kaynakları Yönetimi İlkeler ve Uygulamalar, Nobel Yayın Dağıtım, Ankara 2005, s.85

xiii Alparslan Usal ve Osman Avşar Kurgun, Turizm İşletmelerinde Maliyet Analizleri, Detay Yayıncılık, Ankara 2001, s. 195

xiv Hüseyin Alkış ve Yüksel Öztürk, "Otel İşletmelerinde Motivasyon Faktörleri Üzerine Bir Araştırma”, Elektronik Sosyal Bilimler Dergisi, Cilt 8, Sayı 28, 2009, s. 214

${ }^{x v}$ Ali Yıldırım ve Hasan Şimşek, Sosyal Bilimlerde Nitel Araştırma Yöntemleri. 2. Baskı, Seçkin, Yayıncılık Ankara 2000, s.19

xvi Niyazi Karasar, Bilimsel Araştırma Yöntemi, 20. Baskı, Nobel Yayın Dağıtım, Ankara 2009, s.165- 166

xvii Necla Kolu, Otel İşletmelerinde İnsan Kaynakları Seçim Yöntemleri Personel Bulma ve Seçme Süreci (Örnek Bir Uygulama) Yüksek Lisans

Tezi, Sakarya Üniversitesi Sosyal Bilimler Enstitüsü, 2006, s.119-121
} 